\title{
PARASITOFAUNA OF FIVE FRESHWATER FISHES IN A NIGERIAN FRESHWATER ECOSYSTEM
}

\section{Vincent Chikwendu Ejere', Oscar Ifeanyi Aguzie', Njoku Ivoke', Felicia Nkechi Ekeh', Ngozi Evelyn Ezenwaji1 ${ }^{1}$ Uwakwe Simon Onoja², Joseph Effiong Eyo ${ }^{{ }^{*}}$}

${ }^{1}$ Department of Zoology and Environmental Biology, P.O. Box 3146, University of Nigeria, Nsukka, Enugu State, Nigeria

2 Department of Home Sciences and Nutrition, University of Nigeria, Nsukka, Enugu State, Nigeria

*Corresponding Author, E-mail: joseph.eyo@unn.edu.ng

\section{ARTICLE INFO}

Received: 13 May 2013

Received in revised form: 3 December 2013

Accepted: 3 December 2013

Available online: 10 December 2013

\author{
Keywords: \\ Parasites \\ Freshwater fish \\ Tropical River \\ Prevalence \\ Intensity \\ Sexual dimorphism
}

\begin{abstract}
The parasitic fauna of freshwater fishes of the Warri River, Delta State, Nigeria, with reference to their prevalence, intensity and differences in metazoan parasites between fish sexes, was investigated. A total of 85 fish samples comprising of 21 Tilapia zillii (Cichlidae: Perciformes), 23 Synodontis clarias (Mochokidae: Siluriformes), 23 Chrysichthys nigrodigitatus (Claroteidae: Siluriformes), 16 Hepsetus odoe (Hepsetidae: Characiformes) and 2 Clarias anguillaris (Clariidae: Siluriformes) collected from the Warri River, Delta State, Nigeria, were subjected to parasitological examination. The overall metazoan parasite prevalence was 32.9\%. The metazoan parasites recovered were mainly the acanthocephalans: Neoechinorhynchus prolixum, Pomphorhynchus spp., Acanthocephalus spp. and unidentified acanthocephalan, and nematodes: Camallanus polypteri, Capillaria pterophylli, C. cichlasomae, Procamallanus laeviconchus, Philometroides africanus and Railletnema synodontis. Although the acanthocephalans constituted $75.6 \%$ and nematodes $22.2 \%$ of the parasites recovered, the nematodes had the highest prevalence (23.5\%) compared to the acanthocephalans $(9.4 \%)$. Similarly, variable prevalences were observed for the other metazoan parasite taxa recovered, namely trematoda; Clinostomum complanatum (1.2\%), Leech; Pisciola geometra (2.4\%) and Crustaceans (1.2\%). The highest parasite prevalence $(39.1 \%)$ was observed in S. clarias, while the least $(23.8 \%)$ was observed in T. zillii. Generally, the prevalence of parasites was higher in female (35.7\%) than in the males (31.6\%), although statistically no significant difference was observed in the prevalence by $\operatorname{sex}\left(X^{2}=0.145, P=0.807\right)$. The relatively high overall parasite prevalence in fishes inhabiting the Warri River may be attributed to the relatively high level of pollution.
\end{abstract}

\section{INTRODUCTION}

Parasites are a major concern to freshwater and marine fishes all over the world, and of particular importance in the tropics (lyaji and Eyo, 2008; Bichi and Dawaki, 2010; Ekanem et al., 2011). They constitute a major limiting factor to the growth of farmed fish in Nigeria (Bichi and Yelwa, 2010). The effects of parasites on fish include nutrient devaluation (Hassan et al., 2010); alteration of biology and behaviour (Lafferty, 2008); lowering of immune capabil- ity, induction of blindness (Echi et al., 2009 a, b); morbidity, mortality, growth and fecundity reduction (Nmor et al., 2004) and mechanical injuries depending on the parasite species and load (Echi et al., 2009 a, b). Most supply of fish in Nigeria comes from the riverine ecosystem (Ekanem et al., 2011). Delta State, Nigeria, where the Warri River is located, is a traditional fishing district with a vast coastal land mass in the deltaic area of the Niger River, Nigeria. The rivers, creeks, streams and water reservoirs rich in freshwater fish are its endowment (Agbamu and Orhorhoro, 2007). Tilapia zillii, 


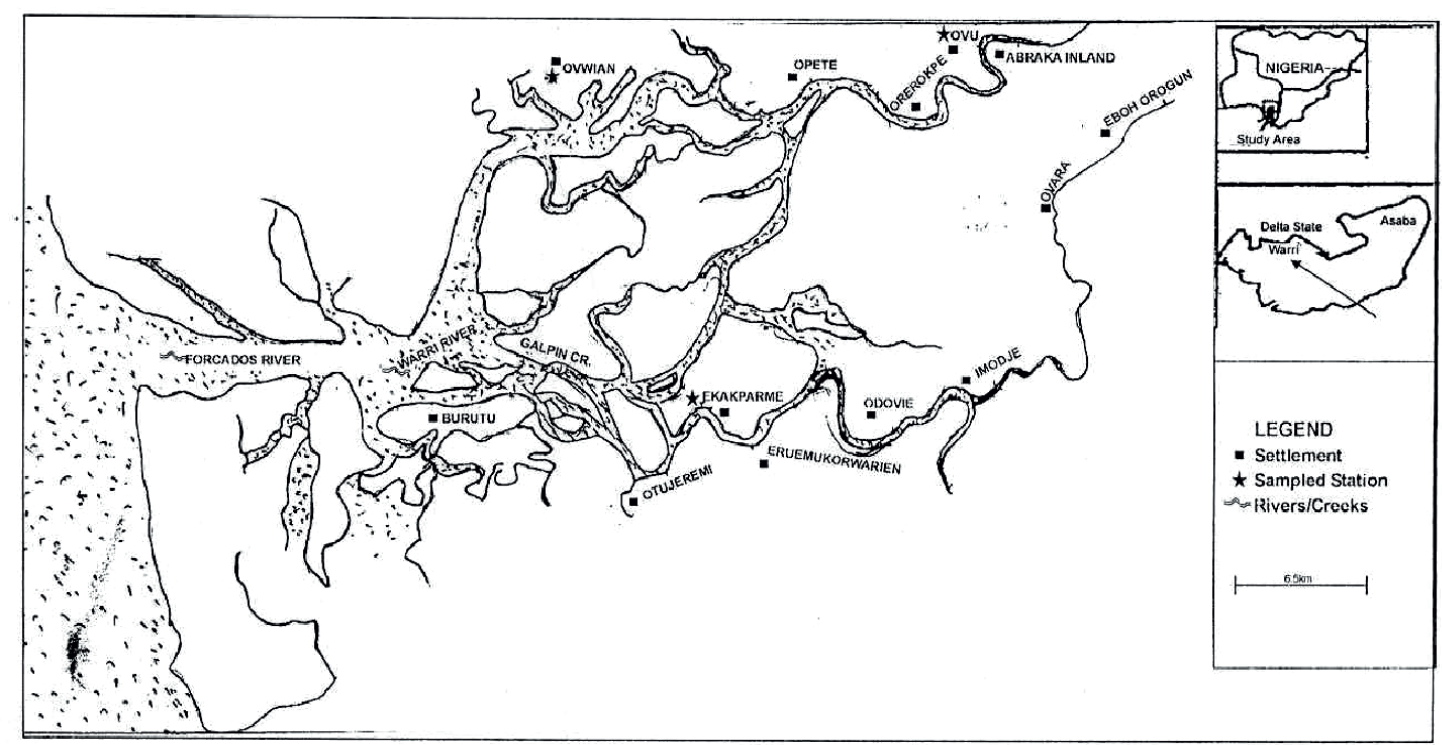

Fig 1. A map of the Warri River showing the study area (Ezemonye et al., 2008)

Hepsetus odoe, Synodontis clarias, Clarias anguillaris and Chrysichthys nigrodigitatus are among the several fish species found in the Warri River, Nigeria. They represent the most abundant fish species with the highest frequency of occurrence in the Warri River and are heavily harvested by fishers because of their high demand (Agbamu and Orhorhoro, 2007).

A review from Nigeria indicated that freshwater fish parasites belong to protozoans, trematode, nematode, cestode, acanthocephalan, copepod and hirudinea groups (lyaji and Eyo, 2008). The presence of Polyonchobothrium and Proteocephalus (Cestoda); Clinostomum, Allocreadium and Diplostomum tragena (Trematoda); Acanthogyrus (Acanthocephala), Camallanus, Procamallanus laeviconchus, Serradactnitis, Spironuora, Spirocamallanus (Nematoda) in freshwater fish in the Osse River, Benin, Nigeria has been reported with $17.1 \%$ overall prevalence of parasite (Okaka and Akhigbe, 1999). Furthermore, the presence of Acanthogyrus, Octospiniferoides, Camallanus, Cucullanus and Wenyonia in freshwater cichlid fish of the Orogodo River, Delta State, Nigeria has been reported (Nmor et al., 2004). Data on freshwater fish parasite in the tropics are vast; the present research was an effort to contribute to existing data on metazoan parasites of freshwater fishes in the Warri River, Nigeria.

\section{MATERIALS AND METHODS}

\section{Study area}

The Warri River (Fig 1.) (Ezemonye et al., 2008) is a relatively large water body with the following geographic coordinates latitude $5^{\circ} 21^{\prime}-6^{\circ} 00^{\prime} \mathrm{N}$ and longitude $5^{\circ} 24^{\prime}-6^{\circ} 21^{\prime}$ $\mathrm{E}$, covering a surface area of about $255 \mathrm{~km}^{2}$ and $150 \mathrm{~km}$ in length (Ezemonye et al., 2008). It derives its source from about $10 \mathrm{~km}$ from Utagba-Uno and flows into the brackish Forcados River that in turn empties into the Atlantic Ocean (Fig 1.). The Warri River is one of the most important coastal rivers of the Niger-Delta region, Nigeria (Olele, 2011).

\section{Fish collection, identification, morphometry and sex determination}

The fish species were obtained in May and June 2012 from fishers in the Makava river fish landing port along the Warri River, Nigeria. Fishes were identified to species level (Teugels et al., 1992; Idodo-Umeh, 2003; Olaosebikan and Raji, 2004). The weight of the fish was taken to the nearest 0.1 $g$ using a triple beam balance, while the standard lengths were taken to the nearest $0.1 \mathrm{~cm}$ using a meter rule. The sex of fish was ascertained by both morphological examination and observation of the presence of testis and ovary using dissecting microscope upon dissection of the fish to expose the gonads (Ayanda, 2009).

\section{Parasitofauna analysis}

External surface of the fish was grossly examined using a hand lens for ectoparasitic species, crustaceans and hirudineans. Smear of scrapings from the skin, fins and gills were also examined for ectoparasites. The fish were sectioned and the alimentary canal, liver, kidney, swim bladder and spleen examined for endoparasites. The excised gastrointestinal tract was carefully sectioned into portions such as oesophagus, intestine and rectum and each portion was then cut open, washed in Petri dish with $0.1 \%$ sodium chloride solution and further rinsed with $0.1 \%$ sodium bicarbonate to enhance parasite search (Paperna, 1996; Marcogliese, 2011). Trematode cysts from the muscle were manually teased to release the metacercariae, which were 
Table 1. Overall prevalence of parasite in the fish examined from the Warri River, Nigeria

\begin{tabular}{lcccc}
\hline \hline Fish species & $\begin{array}{c}\text { Number (\%) of fish } \\
\text { examined }\end{array}$ & $\begin{array}{c}\text { Number (\%) of fish } \\
\text { infected }\end{array}$ & $\begin{array}{c}\text { Number (\%) infected } \\
\text { with Acanthocephala }\end{array}$ & $\begin{array}{c}\text { Number (\%) infected } \\
\text { with nematode }\end{array}$ \\
\hline T. zillii & $21(24.7)$ & $5(5.8)$ & $(0.0)$ & $4(4.7)$ \\
S. clarias & $23(27.1)$ & $9(10.6)$ & $7(8.2)$ & $4(4.7)$ \\
C. nigrodigitatus & $23(27.1)$ & $7(8.2)$ & $(0.0)$ & $7(8.2)$ \\
C. anguillaris & $2(2.4)$ & $1(1.2)$ & $(0.0)$ & $1(1.2)$ \\
H. odoe & $16(18.8)$ & $6(7.1)$ & $1(1.2)$ & $4(4.7)$ \\
Total & $85(100)$ & $28(32.9)$ & $8(9.4)$ & $20(23.5)$ \\
$\chi^{2}$ & & 1.671 & 16.890 & 2.124 \\
P & & 0.796 & 0.002 & 0.713 \\
\hline \hline
\end{tabular}

Table 2. Parasite abundance in the fish examined from the Warri River, Nigeria

\begin{tabular}{lccccccc}
\hline \hline Fish species & $\begin{array}{c}\text { Number } \\
\text { fishes }\end{array}$ & Acanthocephala & Nematode & Trematoda & Hirudinea & Crustacea & Total \\
& infected & Acanther of parasite per taxonomic group & & \\
\hline T. zillii & 5 & 0 & 4 & 0 & 1 & 0 & 5 \\
H. odoe & 6 & 1 & 10 & 0 & 0 & 1 & 12 \\
S. clarias & 9 & 145 & 15 & 0 & 0 & 0 & 160 \\
C. nigrodigitatus & 7 & 0 & 11 & 1 & 1 & 0 & 13 \\
C. anguillaris & 1 & 0 & 3 & 0 & 0 & 0 & 3 \\
Total & 28 & 146 & 43 & 1 & 2 & 1 & 193 \\
Percentage (\%) & & $(75.6)$ & $(22.2)$ & $(0.5)$ & $(1.0)$ & $(0.5)$ & \\
\hline \hline
\end{tabular}

fixed in hot alcohol-formal-acetate (AFA) and preserved in $70 \%$ ethyl alcohol. Digenean trematode metacercariae were stained in Haematoxylin and Eosin (Paperna, 1996). Cestodes from the intestinal tract were placed in $0.1 \%$ sodium chloride solution and refrigerated overnight; this caused the parasite to relax and the scolex to extrude. The resulting cestode was then fixed in hot AFA for 2 minutes and preserved in $70 \%$ ethyl alcohol. Cestodes were stained with aqueous acetocarmine solution (Khalil, 1971). The acanthocephalans were placed in a refrigerator overnight in Petri dishes containing $0.1 \%$ sodium chloride solution (this caused the proboscis of the acanthocephalans to extrude) and then preserved in 70\% ethyl alcohol (Marcogliese, 2011). Leeches collected from fishes were kept in mentholic water to ensure complete relaxation before fixation in 95\% ethyl alcohol (Khalil, 1971). Isolated nematodes, mostly from the gut, were fixed in warm $\left(80^{\circ} \mathrm{C}\right) 10 \%$ neutralized formalin, and preserved in $70 \%$ ethyl alcohol containing 1\% glycerine (Kabata, 1985). The parasites were identified using earlier established identification guides to species level (Yamaguti, 1961, 1963; Soulsby, 1982; Paperna, 1996; Pouder et al., 2011). Voucher specimens of fish and parasites were deposited in the Museum of Natural History, Department of Zoology and Environmental Biology, University of Nigeria, Nsukka, Enugu State, Nigeria.

\section{Data analysis}

Parasite mean intensities and prevalence were calculated as defined by Margolis et al. (1982). The prevalence, abun- dance and intensity of parasite species in hosts examined were analyzed using SPSS (version 17.0). Chi-square test was used to determine significant difference in parasite prevalence between the sexes.

\section{RESULTS}

A total of 85 fish, comprising of 21 Tilapia zillii (Cichlidae: Perciformes), 23 Synodontis clarias (Mochokidae: Siluriformes), 23 Chrysichthys nigrodigitatus (Claroteidae: Siluriformes), 2 Clarias anguillaris (Clariidae: Siluriformes) and 16 Hepsetus odoe (Hepsetidae: Characiformes), were sampled. T. zillii comprised of 11 males and 10 females, $S$. clarias of 14 males and 9 females, $C$. nigrodigitatus of 16 males and 7 females, $C$. anguillaris of 2 males, and $\mathrm{H}$. odoe of 14 males and 2 females.

A total of 193 parasites were recovered from the fish examined. The overall parasite prevalence was $32.9 \%$ (Table 1). There was no significant difference in parasite prevalence for fish species $\left(\chi^{2}=1.671, \mathrm{df}=4, \mathrm{P}=0.796\right)$. The prevalence of infection by fish species were $23.8 \%, 39.1 \%, 30.4 \%, 50.0 \%$ and $37.5 \%$ for $T$. zillii, S. clarias, C. nigrodigitatus, C. anguillaris and $H$. odoe, respectively.

The recovered parasites presented by taxa indicated that the Acanthocephalan represented $75.6 \%$ of the isolated parasites, while nematode constituted $22.2 \%$. Although acanthocephalan were the most abundant, the prevalence of nematode (23.5\%) was higher than the prevalence of acanthocephalan. The identified acanthocephalans belonged to three genera, namely Neoechinorhynchus Blumenbach, 1779, Pomphorhynchus Monticelli, 1905 and Acanthocephalus Anderson, 1867 (Table 2). 
Table 3. Parasite species composition, their prevalence and intensity in fish species collected from the Warri River, Nigeria

\begin{tabular}{|c|c|c|c|c|c|c|c|c|}
\hline Taxa & Parasite species & Fish host & $\begin{array}{l}\text { Number } \\
\text { Examined }\end{array}$ & $\begin{array}{l}\text { Number } \\
\text { infected }\end{array}$ & $\begin{array}{c}\text { Total } \\
\text { Number } \\
\text { of } \\
\text { parasite } \\
\text { recovered }\end{array}$ & $\begin{array}{c}\text { Prevalence } \\
(\%)\end{array}$ & $\begin{array}{c}\text { Mean } \\
\text { abundance }\end{array}$ & $\begin{array}{c}\text { Mean } \\
\text { intensity }\end{array}$ \\
\hline \multirow{5}{*}{ Acanthocephala } & Neoechinorhynchus prolixum & & & 2 & 8 & 8.7 & 0.35 & 4.0 \\
\hline & Pomphorhynchus spp & & & 5 & 31 & 21.7 & 1.35 & 6.2 \\
\hline & Acanthocephalus spp & & & 3 & 14 & 13.0 & 0.61 & 4.7 \\
\hline & Unidentified acanthocephalan & & & 8 & 92 & 34.8 & 4.00 & 11.5 \\
\hline & & S. clarias & 23 & & & & & \\
\hline \multirow{4}{*}{ Nematoda } & Camallanus polypteri & & & 3 & 3 & 13.0 & 0.13 & 1.0 \\
\hline & Capillaria pterophylli & & & 1 & 3 & 4.3 & 0.13 & 3.0 \\
\hline & Procamallanus laeviconchus & & & 2 & 2 & 8.7 & 0.09 & 1.0 \\
\hline & Railletnema synodontis & & & 1 & 6 & 4.3 & 0.26 & 6.0 \\
\hline Acantocephala & Unidentified acanthocephalan & H. odoe & 16 & 1 & 1 & 6.3 & 0.06 & 1.0 \\
\hline \multirow[t]{2}{*}{ Nematoda } & Camallanus polypteri & & & 4 & 9 & 25.0 & 0.56 & 2.3 \\
\hline & Philometroides africanus & & & 2 & 2 & 12.5 & 0.13 & 1.0 \\
\hline Crustacea & Unidentified crustacean & & & 1 & 1 & 6.3 & 0.06 & 1.0 \\
\hline \multirow[t]{2}{*}{ Nematoda } & Procamallanus laeviconchus & T. zillii & 21 & 2 & 2 & 9.5 & 0.10 & 1.0 \\
\hline & Capillaria cichlasomae & & & 1 & 1 & 4.8 & 0.05 & 1.0 \\
\hline Hirudinea & Pisciola geometra & & & 1 & 1 & 4.8 & 0.05 & 1.0 \\
\hline \multirow[t]{3}{*}{ Nematoda } & Camallanus polypteri & C. & 23 & 5 & 6 & 21.7 & 0.26 & 1.2 \\
\hline & Capillaria pterophylli & nigrodigitatus & & 2 & 2 & 8.7 & 0.09 & 1.0 \\
\hline & Procamallanus laeviconchus & & & 1 & 4 & 4.3 & 0.17 & 4.0 \\
\hline \multirow{2}{*}{$\begin{array}{l}\text { Trematoda } \\
\text { Hirudinea }\end{array}$} & Clinostomum complanatum & & & 1 & 1 & 4.3 & 0.04 & 1.0 \\
\hline & Pisciola geometra & & & 1 & 1 & 4.3 & 0.04 & 1.0 \\
\hline \multirow{2}{*}{ Nematoda } & Camallanus polypteri & C. anguillaris & 2 & 1 & 2 & 50.0 & 1.0 & 2.0 \\
\hline & Capillaria pterophylli & & & 1 & 1 & 50.0 & 0.5 & 1.0 \\
\hline
\end{tabular}

Acanthocephalans with invaginated proboscis were all grouped as unidentified acanthocephalan. The nematodes were of five genera, Camallanus Bailliet and Henry, 1915, Procamallanus Baylis, 1923, Capillaria Zeder, 1800, Philometroides Yamaguti, 1935 and Railletnema Prod ${ }^{`}$ hon, 1968. Two groups of nematodes were unidentified. In addition, one trematode parasite of the genus Clinostomum Leidy, 1857 was isolated from the muscle of a C. nigrodigitatus male; as well as a leech - Pisciola de Blainville, 1818 from the buccal cavity and a crustacean. There was no significant difference $(p>0.05)$ in nematode prevalence in examined fish species. There was, however, significant difference $\left(\chi^{2}=16.890, P=0.002\right)$ in acanthocephalan prevalence with high degree of specificity, having $87.5 \%$ prevalence for $S$. clarias and just $12.5 \%$ prevalence for $H$. odoe. Acanthocephalans showed strong specificity for $S$. clarias (Table 3), but with preference for the intestine (Table 4).

Generally, the prevalence of parasites was higher in female fish specimens $(35.7 \%)$ than in males $(31.6 \%)$, although no significant difference was observed in the prevalence by sex $\left(\chi^{2}=\right.$ $0.145, d f=1, P=0.807)$. Similarly, the overall mean abundance and mean intensity of parasite was also higher in female (3.86 and 10.8 , respectively) than in male ( 1.49 and 4.7 , respectively) of the examined fishes (Table 5).

The different species of examined fish showed variation in parasite prevalence when compared by sex. In T. zillii, the male had a parasite prevalence of $18.2 \%$ as against $30.0 \%$ in the female, and no significant difference ( $p>0.05$ ) was observed in the prevalence of parasite by sex in that fish species (Table 5). In $\mathrm{H}$. odoe, no female had parasite while the prevalence for male was 42.9\%; no significant difference was observed in the prevalence of parasite by sex $\left(\chi^{2}=1.371, P=0.500\right)$. Although $28.6 \%$ and $55.6 \%$ parasite prevalence were recorded in male and female S. clarias respectively, the parasite prevalence with sex was not significant $(\mathrm{P}>0.05)$. The $31.3 \%$ and $28.6 \%$ parasite prevalence in males and females of $C$. nigrodigitatus respectively, was not significant either $(p>0.05)$.

\section{DISCUSSION}

The overall prevalence of parasites (32.9\%) was low compared to $59.2 \%$ recorded for fishes in the Niger River at Illushi, Edo State, a Niger Delta area in Nigeria (Oyedineke et al., 2010). It was, however, higher when compared with records by other investigators in the rivers from the same region who reported overall parasite 
Table 4. Prevalence and intensity of parasite in relation to habitat in fish host examined from the Warri River, Nigeria

\begin{tabular}{|c|c|c|c|c|c|c|c|c|}
\hline Parasites & Fish host & $\begin{array}{l}\text { Parasite } \\
\text { habitat }\end{array}$ & $\begin{array}{l}\text { Number } \\
\text { examined }\end{array}$ & $\begin{array}{l}\text { Number } \\
\text { infected }\end{array}$ & $\begin{array}{c}\text { Total } \\
\text { number of } \\
\text { parasite } \\
\text { recovered }\end{array}$ & $\begin{array}{c}\text { Prevalence } \\
\text { (\%) }\end{array}$ & $\begin{array}{c}\text { Mean } \\
\text { abundance }\end{array}$ & $\begin{array}{c}\text { Mean } \\
\text { intensity }\end{array}$ \\
\hline \multirow{6}{*}{$\begin{array}{l}\text { Neoechinorhynchus } \\
\text { prolixum } \\
\text { Pomphorhynchus spp } \\
\text { Acanthocephalus spp } \\
\text { Unidentified } \\
\text { acanthocephalan }\end{array}$} & S. clarias & Intestine & 23 & 2 & 8 & 8.7 & 0.35 & 4.0 \\
\hline & S. clarias & Intestine & 23 & 5 & 31 & 21.7 & 1.35 & 6.2 \\
\hline & S. clarias & Intestine & 23 & 3 & 14 & 13.0 & 0.61 & 4.7 \\
\hline & S. clarias & Intestine & 23 & 7 & 91 & 30.4 & 3.96 & 13.0 \\
\hline & H. odoe & Stomach & 16 & 1 & 1 & 4.3 & 0.04 & 1.0 \\
\hline & & Intestine & 16 & 1 & 1 & 6.3 & 0.06 & 1.0 \\
\hline \multirow[t]{10}{*}{ Camallanus polypteri } & T. zillii & Stomach & 21 & 1 & 1 & 4.8 & 0.05 & 1.0 \\
\hline & & Intestine & 21 & 1 & 1 & 4.8 & 0.05 & 1.0 \\
\hline & H. odoe & Stomach & 16 & 2 & 2 & 12.5 & 0.13 & 1.0 \\
\hline & & Intestine & 16 & 2 & 7 & 12.5 & 0.44 & 3.5 \\
\hline & S. clarias & Intestine & 23 & 1 & 1 & 4.3 & 0.04 & 1.0 \\
\hline & C. nigrodigitatus & Stomach & 23 & 3 & 4 & 13.0 & 0.17 & 1.3 \\
\hline & & Intestine & 23 & 1 & 1 & 4.3 & 0.04 & 1.0 \\
\hline & & Buccal cavity & 23 & 1 & 1 & 4.3 & 0.04 & 1.0 \\
\hline & C. anguillaris & Stomach & 2 & 1 & 1 & 50.0 & 0.50 & 1.0 \\
\hline & & Intestine & 2 & 1 & 1 & 50.0 & 0.50 & 1.0 \\
\hline \multirow{4}{*}{$\begin{array}{l}\text { Capillaria cichlasomae } \\
\text { Capillaria pterophylli }\end{array}$} & T. zillii & Intestine & 21 & 1 & 1 & 4.8 & 0.05 & 1.0 \\
\hline & S. clarias & Intestine & 23 & 1 & 3 & 4.3 & 0.13 & 3.0 \\
\hline & C. nigrodigitatus & Intestine & 23 & 2 & 2 & 8.7 & 0.09 & 1.0 \\
\hline & C. anguillaris & Intestine & 2 & 1 & 1 & 50.0 & 0.50 & 1.0 \\
\hline \multirow{3}{*}{$\begin{array}{l}\text { Procamallanus } \\
\text { laeviconchus }\end{array}$} & S. clarias & Intestine & 23 & 1 & 1 & 4.3 & 0.04 & 1.0 \\
\hline & & Stomach & 23 & 1 & 1 & 4.3 & 0.04 & 1.0 \\
\hline & C. nigrodigitatus & Intestine & 23 & 1 & 4 & 4.3 & 0.17 & 4.0 \\
\hline \multirow{3}{*}{$\begin{array}{l}\text { Railletnema } \\
\text { synodontis } \\
\text { Philometroides } \\
\text { africanus }\end{array}$} & & & & & & & & \\
\hline & S. clarias & Intestine & 23 & 1 & 6 & 4.3 & 0.26 & 6.0 \\
\hline & H. odoe & Stomach & 16 & 2 & 2 & 12.5 & 0.13 & 1.0 \\
\hline $\begin{array}{l}\text { Clinostomum } \\
\text { complanatum }\end{array}$ & C. nigrodigitatus & Muscle & 23 & 1 & 1 & 4.3 & 0.04 & 1.0 \\
\hline \multirow{2}{*}{ Pisciola geometra } & T. zillii & Buccal cavity & 21 & 1 & 1 & 4.8 & 0.05 & 1.0 \\
\hline & C. nigrodigitatus & Buccal cavity & 23 & 1 & 1 & 4.3 & 0.04 & 1.0 \\
\hline Crustacea & H. odoe & Skin & 16 & 1 & 1 & 6.3 & 0.06 & 1.0 \\
\hline
\end{tabular}

prevalence of $17.1 \%$ in the Osse River, $6.9 \%$ in the Okhuo River and $3.3 \%$ in the Great Kwa River (Okaka and Akhigbe, 1999; Edema et al., 2008; Ekanem et al., 2011). These variations in the rate of parasitism could be attributed to abiotic and biotic conditions of the environments where the studies were carried out (Koskivaara, 1992; Thompson and Larsen, 2004). Unfavourable conditions may offset fish physiology favouring parasite infestation and invasion. Rohlenova et al. (2011) has reported that unfavourable temperature may alter fish physiology including immune function favouring parasite invasion. Pollution of the fish environment also contributes to parasitizing of fish significantly (Kelly et al., 2010). The relatively high prevalence of parasites in the examined fish in this study may be attributed to the relatively high pollution of the Warri River, Nigeria (Aghoghovwia, 2011; Olele, 2012). The high prevalence of acanthocephalan and nematode parasites may be attributed to the presence of appropriate intermediate host (Nmor et al., 2004), trophic linkage with the fish (Lagrue et al., 2011) and efficiency in transmission of parasite to fish host (lyaji et al., 2009). It is important to note that even though $C$. anguillaris had parasite prevalence of $50.0 \%$, its prevalence may not represent the exact prevalence of parasite in C. anguillaris in the Warri River because only two specimens of this fish species were encountered during the fish collection. The highest prevalence of parasites in S. clarias may be due to several factors which include feeding habit and diet of fish (Rolbiecki, 2006), habitat (Koskivaara, 1992), immuno-competence of the fish (Folstad and Karter, 1992), as well as the behavioural pattern of the fish. Feeding on gastropods, worms, crustaceans and detritus by $S$. clarias may facilitate infection by parasites (Lagrue et al., 2011). Neoechinorhynchus, Pomphorhynchus, Acanthocephalus and the unidentified acanthocephalans showed the highest abundance in the Warri River, and were limited almost to 
Table 5. Overall prevalence and intensity of parasites in the different fish species examined from the Warri River, Nigeria in relation to sex

\begin{tabular}{|c|c|c|c|c|c|}
\hline Fish sex & $\begin{array}{l}\text { Number (\%) of } \\
\text { fish examined }\end{array}$ & $\begin{array}{l}\text { Number (\%) of } \\
\text { fish infected }\end{array}$ & $\begin{array}{c}\text { Number (\%) } \\
\text { of parasite } \\
\text { recovered }\end{array}$ & $\begin{array}{c}\text { Mean } \\
\text { abundance }\end{array}$ & Mean intensity \\
\hline \multicolumn{6}{|l|}{ T. zillii } \\
\hline Male & 11(52.4) & $2(18.2)$ & $2(40.0)$ & 0.18 & 1.0 \\
\hline Female & $10(47.6)$ & $3(30.0)$ & $3(60.0)$ & 0.30 & 1.0 \\
\hline Total & $\begin{array}{r}21(100) \\
\chi^{2}=0.403,\end{array}$ & $\begin{array}{c}5(23.8) \\
p=0.635^{*}\end{array}$ & $5(100)^{\prime}$ & 0.24 & 1.0 \\
\hline \multirow{4}{*}{$\begin{array}{l}\text { H. odoe } \\
\text { Male } \\
\text { Female } \\
\text { Total }\end{array}$} & & & & & \\
\hline & $14(87.5)$ & $6(42.9)$ & $12(100)$ & 0.86 & 2.0 \\
\hline & $\begin{array}{l}2(12.5) \\
16(100)\end{array}$ & $6(0.0)$ & $12(100)$ & $\begin{array}{l}0.00 \\
0.86\end{array}$ & $\begin{array}{l}0.0 \\
20\end{array}$ \\
\hline & $\chi^{2}=1.371$ & $p=0.500^{*}$ & & & \\
\hline \multirow{3}{*}{$\begin{array}{l}\text { S. clarias } \\
\text { Male } \\
\text { Female } \\
\text { Total }\end{array}$} & $14(60.9)$ & $4(28.6)$ & $58(36.3)$ & 4.14 & \\
\hline & $9(39.1)$ & $5(55.6)$ & $102(36.3)$ & 11.33 & 20.4 \\
\hline & $23(100)$ & $9(39.1)$ & $160(100)$ & 6.96 & 17.8 \\
\hline \multirow{4}{*}{$\begin{array}{l}\text { C. nigrodigitatus } \\
\text { Male } \\
\text { Female } \\
\text { Total }\end{array}$} & $\chi^{2}=1.675$, & $p=0.383^{*}$ & & & \\
\hline & 16(69.6) & $5(31.3)$ & $10(76.9)$ & 0.63 & 2.0 \\
\hline & $7(30.4)$ & $2(28.6)$ & $3(23.1)$ & 0.43 & 1.5 \\
\hline & $23(100)$ & $7(30.4)$ & $13(100)$ & 0.57 & 1.9 \\
\hline \multirow{3}{*}{$\begin{array}{l}\text { C. anguillaris } \\
\text { Male } \\
\text { Female } \\
\text { Total }\end{array}$} & $\chi^{2}=0.011$ & $p=1.000^{*}$ & & & \\
\hline & $2(100)$ & $1(50.0)$ & $3(100)$ & 1.50 & \\
\hline & $\begin{array}{l}(0.0) \\
2(100)\end{array}$ & $1(50)$ & $\begin{array}{l}(0.0) \\
3(0.0)\end{array}$ & $\begin{array}{l}(0.0) \\
1.50\end{array}$ & $\begin{array}{l}(0.0) \\
3.0\end{array}$ \\
\hline \multicolumn{6}{|l|}{ Total (General) } \\
\hline Male & $57(67.1)$ & $18(31.6)$ & $85(44.0)$ & 1.49 & 47 \\
\hline \multirow[t]{2}{*}{ Female } & 28 (32.9) & $10(35.7)$ & $108(56.0)$ & 3.86 & 10.8 \\
\hline & $\chi^{2}=0.145$ & $P=0.807^{*}$ & & & \\
\hline
\end{tabular}

${ }^{*} P$ values determined by chi square test

S. clarias. The high prevalence for S. clarias may be attributed to the suitability of the fish host in provision of appropriate ecological requirements of the parasite (Akinsanya et al., 2008; Lagrue et al., 2011). Similarly, the high nutritional content of the S. clarias intestine may possibly account for their preference, restriction and abundance in them (Akinsanya et al., 2008). Two parasite genera, Camallanus and Capillaria, were present in all fish species. Thus they show no generic specificity for fish species but may show species specificity thus; Capillaria cichlasomae in Tilapia zillii and C. pterophylli in other fish species. Furthermore, Capillaria unlike Camallanus exhibited site-specificity with preference for the fish intestine. The very small size of Camallanus and, possibly, less nutritional demand may have necessitated their non-site specificity. Specificity generally is a product of adaptation (Lively and Dybdahl, 2000). Nematodes of the genera Railletnema and Philometroides were only recorded in S. clarias and $\mathrm{H}$. odoe, respectively, maybe indicating species specificity of these parasites. Philometroides africanus has been reported to parasitize the freshwater African pike $(H$. odoe) from Botswana (Moravec and Van-As, 2001).

Parasitism in fish has been reported to be sex biased, with males suffering greater susceptibility. This sex linked parasitism has been explained as resulting from difference in reproductive investment by male and female fish (Skarstein et al., 2001; Simkova et al., 2008). Immuno-suppression by steroid hormone during spawning in males has been suggested as a major fac- tor contributing to the greater susceptibility of males to parasite invasion (Folstad and Karter, 1992). Other factors suggested include competition for mate (Folstad and Karter, 1992) and cost of territorial defense (Reimchen, 2001). But contrary to these aforementioned observations, parasite prevalence obtained in the present study for female T. zillii $(30.0 \%)$ and S. clarias (55.6\%) were higher than in males $(18.2 \%$ and $28.6 \%$, respectively). Numbers of females in $\mathrm{H}$. odoe were only two and so may not be suitable to ascertain for parasite prevalence due to sex. The overall parasite prevalence in females (35.7\%) was also higher than that in males (31.6\%). The observed higher overall parasite prevalence in females may be suggestive of difference in ecological requirements between male and female fish (lyaji et al., 2009) and greater susceptibility of ovigerous females to parasite (Simkova et al., 2008). However, the present observed difference in parasite prevalence according to sex was not significant $(p>0.05)$. The non-significant difference in parasite prevalence stratified by sex supports an earlier observation by Akinsanya et al. (2007) who recorded a non-significant $(p>0.05)$ difference in the infection rate of male $(37.7 \%)$ and female (35.5\%) of Malapterurus electricus in Lekki Lagoon, Lagos State, Nigeria. In Bagauda Fish Farm, Kano, female Clarias gariepinus had higher occurrence of both the gill $(20.7 \%)$ and gastrointestinal tract $(34.6 \%)$ of parasites than that of the gill $(11.8 \%)$ and gastrointestinal tract $(23.6 \%)$ of males, although the difference was not significant ( $p>0.05$ ) (Bichi and Yelwa, 2010). Similarly, 
a non-significant difference $(p>0.05)$ in the infection rate of females and males of four fish species (Puntius schwanenfeldii, Puntius gonionotus, Hampala macrolepidoata and Notopterus notopterus) examined at Tasik Merah, Perak, Peninsular, Malaysia have been reported (Rahman and Saidin, 2011).

The high prevalence of parasites in the Warri River, Nigeria is a setback to fish productivity in the zone. Parasite invasion and establishment in a fish compromise the efficiency of the fish in preventing further infection, lowering the fish reproductive efficiency and feed utilization. Thus, to ensure optimal productivity of fish in the Warri River, further studies need to be undertaken in order to ascertain the major causes of the high rate of infection, and the appropriate measures to be taken to ameliorate it.

\section{ACKNOWLEDGEMENTS}

We are indebted to the Department of Zoology and Environmental Biology, University of Nigeria, Nsukka, Nigeria for providing full laboratory facilities during the study. We are also thankful to the numerous fishermen at the Makava landing port along the Warri River, Nigeria, and Mr. Simon Ugwu and Mr. Sabestine Ali for their assistance in fish collection. We are also thankful to Mr. and Mrs. I. Aguzie for the provision of accommodation and freezing facilities during the study.

\section{Sažetak}

\section{PARAZITOFAUNA PET SLATKOVODNIH RIBA U NIGERIJSKOM SLATKOVODNOM EKOSUSTAVU}

Ovo istraživanje bavi se proučavanjem parazitofaune slatkovodnih riba iz rijeke Warri u državi Delti u Nigeriji s obzirom na zastupljenost, intenzitet pojave i razlike u višestaničnim parazitima kod različitih spolova. Parazitološkom pregledu podvrgnuto je ukupno 85 jedinki ribe iz rijeke Warri u državi Delti u Nigeriji: 21 Tilapia zillii (Cichlidae: Perciformes), 23 Synodontis clarias (Mochokidae: Siluriformes), 23 Chrysichthys nigrodigitatus (Claroteidae: Siluriformes), 16 Hepsetus odoe (Hepsetidae: Characiformes) i dvije Clarias anguillaris (Clariidae: Siluriformes). Ukupna zastupljenost višestaničnih parazita bila je $32,9 \%$. Otkriveni višestanični paraziti uglavnom su bili akantocefali, Neoechinorhynchus prolixum, Pomphorhynchus spp., Acanthocephalus spp., a isto tako i neidentificirani akantocefali i nematode, Camallanus polypteri, Capillaria pterophylli, C. cichlasomae, Procamallanus laeviconchus, Philometroides africanus i Railletnema synodontis. Među otkrivenim parazitima akantocefala je bilo $75,6 \%$, a nematoda $22,2 \%$, no usprkos manjem postotku, nematode su imale veću zastupljenost $(23,5 \%)$ u usporedbi s akantocefalima $(9,4 \%)$. Isto tako, praćena je i zastupljenost drugog višestaničnog parazita - trematoda (metilja): Clinostomum complanatum (1,2\%), zatim pijavica (Leech); Pisciola geometra $(2,4 \%)$ i račića (Crustaceans) (1,2\%). Najveća zastupljenost parazita zabilježena je kod S. Clarias, a najmanja $(23,8 \%)$ kod T. zillii. Sveukupno gledajući, zastupljenost parazita bila je veća kod ženki (35,7\%) nego kod mužjaka $(31,6 \%)$, iako statistički nema velike razlike u zastupljenosti parazita po spolu ( $\chi 2=0,145, \mathrm{P}=0,807)$. Relativno visoka ukupna zastupljenost parazita kod riba može se pripisati relativno visokoj razini onečiščenja.

Ključne riječi: paraziti, slatkovodna riba, tropska rijeka, zastupljenost, intenzitet, spolni dimorfizam

\section{REFERENCES}

Agbamu, J. U., Orhorhoro, W. C. (2007): Adoption of aquaculture management techniques in Delta State. Food, Agriculture and Environment, 5, 2, 243-246.

Aghoghovwia, O. A. (2011): Physico-chemical characteristics of Warri River in the Niger Delta region of Nigeria. Journal of Environmental Issues and Agriculture in Developing Countries, 3, 2, 40-46.

Akinsanya, B., Otubanjo, O. A., Hassan, A. A. (2007): Helminth parasites of Malapterurus electricus (Malapteruridae) from Lekki Lagoon, Lagos, Nigeria. Journal of American Science, 3, 3, 1-6.

Akinsanya, B., Hassan, A. A., Adeogun, A. O. (2008): Gastrointestinal helminth parasites of the fish Synodontis clarias (Siluriformes: Mochokidae) from Lekki lagoon, Lagos, Nigeria. Revista de Biologia Tropical, 56, 4, 2021-2026.

Ayanda, O. I. (2009): Comparison of parasitic health infection between the sexes of Clarias gariepinus from Asa Dam Ilorin, north-central Nigeria. Scientific Research and Essays, 4, 4, 357-360.

Bichi, A. H., Dawaki, S. S. (2010): A survey of the ectoparasites on the gills, skin and fins of Oreochromis niloticus at Bagauda fish farm, Kano, Nigeria. Bayero Journal of Pure and Applied Sciences, 3, 1, 83-86.

Bichi, A. H., Yelwa, S. I. (2010): Incidence of piscine parasites on the gill and gastrointestinal tract of Clarias gariepinus (Teugels) at Bagauda fish farm, Kano. Bayero Journal of Pure and Applied Sciences, 3, 1, 104-107.

Echi, P. C., Eyo, J. E., Okafor, F. C. (2009 a): Co-parasitism and morphometrics of three clinostomatids Digenea: Clinostomatidae; in Sarotherodon melanotheron from a tropical freshwater lake. Animal Research International, 6, 2, 982-986.

Echi, P. C., Okafor, F. C., Eyo, J. E. (2009 b): Co-infection and morphometrics of three clinostomatids Digenea: Clinostomatidae; in Tilapia guinensis Bleeker, 1862 from Opi lake, Nigeria. BioResearch, 7, 1, 432-436.

Edema, C. U., Okaka, C. E., Oboh, I. P., Okogub, B. O. (2008): A preliminary study of parasitic infections of some fishes from Okhuo River, Benin City, Nigeria. International Journal of Biomedical Health Science, 4, 3, 107-112.

Ekanem, A. P., Eyo, V. O., Sampson, A. F. (2011): Parasites of landed fish from great Kwa River, Calabar, Cross River State, Nigeria. International Journal of Fisheries and Aquaculture, 3, 12, 225-230.

Ezemonye, L. I. N., Ikpesu, T. O., Ilechie, I. (2008): Distribution of diazinon in water, sediment and fish from Warri River, Niger 
Delta, Nigeria. Jordan Journal of Biological Science, 1, 2, 7783.

Folstad, I., Karter, A. J. (1992): Parasites, bright males and immunocompetence handicap. American Naturalist, 139, 603-622.

Hassan, A. A., Akinsanya, B., Adegbaju, W. A. (2010): Impacts of helminth parasites on Clarias gariepinus and Synodontis clarias from Lekki Lagoon, Lagos, Nigeria. Reports and Opinions, 2, 11, 42-48.

Idodo-Umeh, G. O. (2003): Freshwater fishes of Nigeria taxonomy, ecological note, diet and utilization. Idodo-Umeh Publishers, Edo State, Nigeria.

Iyaji, F. O., Etim, L., Eyo, J. E. (2009): Parasite assemblages in fish hosts. Bio-Research, 7, 2, 561-570.

Iyaji, F. O., Eyo, J. E. (2008): Parasites and their freshwater fish host. Bio-Research, 6, 1, 328-338.

Kabata, Z. (1985): Parasites and diseases of fish cultured in the tropics. Taylor and Francis, London.

Kelly, D. W., Poulin, R., Tompkins, D. M., Townsend, C. R. (2010): Synergistic effects of glyphosate formulation and parasite infections and survival. Journal of Applied Ecology, 47, 498-504.

Khalil, L. F. (1971): Checklist of the helminth parasites of African freshwater fishes. Commonwealth Institute of Helminthology, St Albans, England, Technical Communication, 42, 1-80.

Koskivaara, M. (1992): Environmental factors affecting monogeneans parasite on freshwater fishes. Parasitology Today, 8, 10, 339-342.

Lafferty, K. D. (2008): Ecosystem consequences of fish parasites. Journal of Fish Biology, 73, 2083-2093.

Lagrue, C., Kelly, D. W., Hicks, A., Poulin, R. (2011): Factors influencing infection patterns of trophically transmitted parasites among a fish community: host diet, host-parasite compatibility or both. Journal of Fish Biology, 79, 406-485.

Lively, C. M., Dybdahl, M. F. (2000): Parasite adaptation to locally common host genotypes. Nature, 405, 679-681.

Marcogliese, D. L. (2011): Parasitology Module Steering Committee PMSC. Protocols for measuring biodiversity: parasites of fishes in freshwater update. Protocols Manual for Water Quality Sampling in Canada. Ecological Monitoring and Assessment Network EMAN, Canada.

Margolis, L., Esch, G. W., Holmes, J. C., Kuris, A. M., Schad, G. A. (1982): The use of ecological terms in parasitology (Report of the American Society of Parasitologists). Journal of Parasitology, 68, 131-133.

Moravec, F., Van-As, J. G. (2001): Philometroides africanus sp. n. (Nematoda: Philometridae), a new tissue parasite of the African pike Hepsetus odoe (Pisces) in Botswana. Folia Parasitologica, 48, 127-131.

Nmor, J. C., Egwunyenga, A. O., Ake, J. E. G. (2004): Observation of the intestinal helminth parasites of cichlid in the upper reaches of River Orogodo, a freshwater body in Delta State, Southern Nigeria. Tropical Freshwater Biology, 13, 131-136.

Okaka, C. E., Akhigbe, J. E. (1999): Helminth parasites of some tropical freshwater fish from Osse River in Benin, Southern Nigeria. Tropical Freshwater Biology, 8, 41-48.

Olaosebikan, B. D., Raji, A. (2004): Field guide to Nigerian fresh- water fishes. Federal College of Freshwater Fisheries Technology, New Bussa, Nigeria.

Olele, N. F. (2011): Diet composition, length, weight relationship and condition factor of Hyperopisus bebe occidentalis Lacepede 1803; caught in Warri River. Journal of Basic and Applied Science Research, 1, 9, 998-1005.

Olele, N. F. (2012): Concentration of some heavy metals in Escravos River, Warri, Delta State, Nigeria. Journal of Animal Scientist, 1, 1, 1-4.

Oyedineke, N. E., Obi, U., Ofoegbu, P. U., Ukogo, I. (2010): Helminth parasites of some freshwater fish from River Niger at Illushi, Edo State, Nigeria. Journal of American Science, 6, 3, 16-21.

Paperna, I. (1996): Parasites, infection and diseases of fishes in Africa-an update. CIFA Tech Paper, 31, 1-200.

Pouder, D. B., Curtis, E. W., Yanong, R. P. E. (2011): Common freshwater fish parasites pictorial guide: Sessile ciliates. Accessed: $12^{\text {th }}$ April, 2012. Available from: http: edis.ifas.ufl.edu/FA-107.

Rahman, W. A., Saidin, H. (2011): Relationship between sex and parasite intensity in four freshwater fish species from TasikMerah, Peninsular Malaysia. World Journal of Zoology, 6, 4, 370-374.

Reimchen, T. E. (2001): Ecological causes of sex-biased parasitism in three spine stickle back. Biological Journal of the Linnaeus Society, 73, 51-63.

Rohlenova, K., Morand, S., Hyršl, P., Tolarová, S., Flajšhans, M., Sinkova, A. (2011): Are fish immune systems really affected by parasites? An immunological study of common carp (Cyrinus carpio). Parasites and Vectors, 40, 120-138.

Rolbiecki, L. (2006): Correlation between the occurrence of parasites and body length of roach carp beam European perch, zander and ruffe in the Vistula Lagoon estuary. International Journal of Oceanography and Hydrobiology, 35, 3, 257-267.

Skarstein, F., Folstad, I., Liljeda, S. (2001): Whether to reproduce or not: Immune suppression and costs of parasites during reproduction in the Arctic Charr. Canadian Journal of Zoology, 79, 271-278.

Simkova, A., Lafond, T., Ondračkova, M., Jurajda, P., Ottova, E., Morand, S. (2008): Parasitism, life history traits and immune defense in cyprinid fish from Central Europe. BMC Evolutionary Biology, 8, 29-40.

Soulsby, E. J. L. (1982): Helminthes, arthropods and protozoa of domesticated animals, Seventh Edition, Bailliere Tindal, London.

Teugels, G. G., Reid, McG. G., King, R. P. (1992): Fishes of the Cross River Basin (Cameroon, Nigeria): Taxonomy zoogeography, ecology and conservation. Annales Sciences Zoologiques, 266, 1-132.

Thompson, L. C., Larsen, R. (2004): Fish habitat in freshwater stream. Farm Water Quality Planning FWOP; Reference Sheet 10.3, Publication 8112. University of California, California.

Yamaguti, S. (1961): Systema helminthium: The nematodes of vertebrates. Interscience Publisher, New York.

Yamaguti, S. (1963): Systema helminthium: The acanthocephala. Interscience Publisher, New York. 